\title{
Registration of untypical 3D objects in Polish cadastre - do we need 3D cadastre?
}

\author{
Karabin Marcin \\ Warsaw University of Technology, Faculty of Geodesy and Cartography \\ Department of Cadastre and Land Management, Plac Politechniki 1, 00-661 Warsaw, Poland \\ e-mail: M.Karabin@interia.pl
}

Received: 12 July 2012/Accepted: 26 October 2012

\begin{abstract}
Polish cadastral system consists of two registers: cadastre and land register. The cadastre register data on cadastral objects (land, buildings and premises) in particular location (in a two-dimensional coordinate system) and their attributes as well as data about the owners. The land register contains data concerned ownerships and other rights to the property. Registration of a land parcel without spatial objects located on the surface is not problematic. Registration of buildings and premises in typical cases is not a problem either. The situation becomes more complicated in cases of multiple use of space above the parcel and with more complex construction of the buildings.

The paper presents rules concerning the registration of various untypical 3D objects located within the city of Warsaw. The analysis of the data concerning those objects registered in the cadastre and land register is presented in the paper. And this is the next part of the author's detailed research. The aim of this paper is to answer the question if we really need 3D cadastre in Poland.
\end{abstract}

Keywords: 3D cadastre, base map, cadastral system

\section{Introduction}

The basic legal act concerning geodesy and cartography in Poland - The Act of May 17, 1989 The Geodetic and Cartographic Law (Polish Parliament, 2010), defines the cadastre in Poland in the following way "the uniform at the national scale, and systematically updated set of information on lands, buildings and premises, their owners and other individuals or entities, who possess those lands, buildings and premises".

In its further part, the Act defines the details and specifies the scope of data. It states, that: the cadastre includes information on:

1) lands - their location, boundaries, area, land use types, soil classes, designation in land register or files of documents, if they exist for given real estates, including the discussed lands,

2) buildings - their location, intended use, useful functions, general technical specifications,

3) premises - their location, functions and size. 
Considering the above, three types of cadastral objects (land parcels, buildings and premises), as well as cadastral subjects (owners and/or possessors) are distinguished in the cadastre.

The scope of data registered in the cadastre is specified in details by the Instruction to the Legal Act, i.e. the Decree of the Minister of Regional Development and Housing of March 29, 2001 (Minister of Regional Development and Housing, 2001).

Definition of a land parcel and limitation of the extent of the property rights to real estates were described by the author in details in Karabin (2011b). Definition and registered data concerning buildings are specified in $\S 63$ of the Cadastral Law and were described by the author in details in Karabin (2011b).

Issues concerning registration of premises in the cadastre have been discussed by the author in the paper "Registration of the Premises in 2D Cadastral System in Poland", which was presented during the FIG Working Week 2011 in Marrakech, Morocco (Karabin, 2011a).

In this paper there are shown the rules concerned with the registration of various untypical 3D objects located within the city of Warsaw, the capital of Poland. There are presented the results of analysis of the data concerning those objects registered in Cadastre and Land Register. Registration of underground objects is not the subject of cadastral registration in Poland, but the spatial information about those objects is included in base maps.

This is the next part of the author's detailed research in this field. The first results were published in the paper "Rules concerned registration of the spatial objects in Poland in the context of 3D cadaster's requirements" presented during $2^{\text {nd }}$ International Workshop on 3D Cadastres Delft in, Netherlands on 16-18 November 2011. The aim of the current paper is to answer the question if we really need 3D cadastre in Poland.

In many countries various activities concerned with $3 \mathrm{D}$ cadastres have been conducted. The start of the researches related this issue we can assume by the $1^{\text {st }}$ Workshop on 3D cadastres held in Delft in November 2001. Workshop held in Delft in the year 2011 allowed for detailed analysis of present conditions and directions of development of cadastral solutions, existing in the world, related to registration of 3D objects. Initial researches concerned with 3D cadastres are conducted in Latin countries (Erba and Graciani, 2011), Croatia (Vucic et al., 2011), Nepal (Acharya, 2011), Hungary (Ivan, 2011). Aspect of height system for 3D cadastres was detailed analysed by Austrian research's workers (Navratil and Unger, 2011). Tsiliakou and Dimopoulou (2011) have compared situation in the Netherlands, Australia, Israel and Greece. 3D topology in cadastral systems is a very significant direction of researches in China (Ying et al., 2011), Australia and Netherlands (Thompson and Oosterom, 2011). Data modelling in 3D cadastres is an important topic of researches in Australia and Netherlands (Aien et al., 2011). Very complex and advanced technical solutions (prototypes) are drawn up by Asian and Dutch experts (Guo et al., 2011).

There does not exist a single best solution for a 3D cadastre. Further researches on technical, organizational and legal aspects of 3D cadastres are necessary, also in Poland. 


\section{Analysis of registration of untypical 3D objects in the cadastre}

In this section the author presents results of tests concerning selected, untypical spatial objects in the cadastre. In the majority of cases the term "untypical" refers to typical cadastral objects, i.e. buildings, which - due to their complex constructions - become "untypical" cadastral objects in the process of their registration in the conventional cadastre. At present, modern architecture has permanently entered the urban landscape, and the cadastre, unfortunately, remains in its traditional approach - as the system which registered the spatial objects, but in the $2 \mathrm{D}$ approach. In this section such objects, which - by definition - are not cadastral objects, but in other countries their presence in the cadastre is considered. These are underground tunnels, metro and other objects of the underground infrastructure.

For each case analysis of cadastral registration of real estates, in the descriptive part has been performed (also for the buildings register), on the cadastral map in land register. Records on the base map were also analysed and investigated objects were photographically documented.

This is the next part of the author's detailed research. The first results were published in the paper "Rules concerned registration of the spatial objects in Poland in the context of 3D cadastre's requirements" (Karabin, 2011b).

\subsection{Underground garage crossing parcels and above ground connector - test object No 1}

The first test object is the building of one of state institutions located in the centre of Warsaw, in Krasiński Square. It is presented in the figure 1. This building is partially located over the street, which consists of two cadastral parcels No 19 and No 49/1. Generally the building is located on land parcels: No 66, No 49/1, No 48/1 and No $1 / 2$ from the cadastral block 5-02-08 and on land parcels: No 19 and No 3/3 from the cadastral block 5-02-07. Additionally, the underground two level parking area is located on the cadastral parcel No 3/4. It is used by employees of institutions which have their offices at the above building, as well as by inhabitants and tourists, since the discussed building is located close to the monumental, old part of Warsaw. Therefore the parking area is accessible for all. What is important, exits from the parking area onto the terrain surface are located in the parts of the building under the above-ground connector, i.e. on parcels No 19 and No 49/1 (the parking area is connected under the ground with the discussed building and situated under the street).

Some initial investigations concerning that object were performed as early as in 2008 (investigation concerned only the over ground connector). Those investigations were supervised by the author and they were performed by Katarzyna Góźdź within the frames of the master's thesis „Analysis of foreign solutions in the field of registration of three-dimensional (3D) objects in the cadastre and possibilities to implement those solutions in Poland" (Góźdź, 2008). 


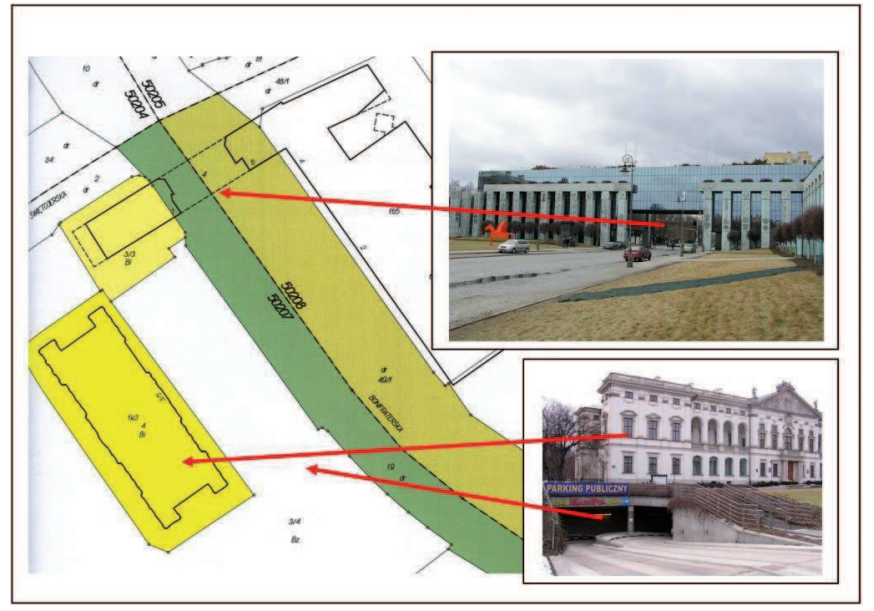

Fig. 1. Test object No 1 - cadastral map

Source: The Office of Geodesy and Cadastre for the City of Warsaw - map, photographs - author

Complete analysis of records in the descriptive part of the cadastre as well as data from the land register and base map performed by the author in the year 2012 show the following:

- Cadastral parcels located within the area of the investigated object are owned by various owners, but all of them are public entities (owners: the State Treasury or the City of Warsaw, entities, which are real administrators of the real estate, are: the City Road Management, the Supreme Court, the President of Warsaw).

- "Conflicts" with private entities do not occur.

- There is no land register (not obligatory in Poland) for those cadastral parcels, on which the road is located; therefore it is not possible to register limited material rights for those real estates (it is important when a part of the building, the so-called, above-ground "connector", is located within the space of those parcels).

- In the descriptive part of cadastre (register of the buildings) the building is registered as one object; it is also stated that the building is located also on land parcels No 19 and No 49/1.

- On the cadastral map two "separate" objects exist.

- As it turns out from the records in the land register for the parcels No 3/3 and No $3 / 4$, a telecommunication company has the right to use the underground part of the building, for an unlimited time, according to a specified charge; additionally, the parcel, under which the parking area is located (parcel No 3/4), is specified in the cadastre and in the land register, as "recreation area".

- For the parcels No 19 and No 49/1 land registers have not been established; the analysis of the land register for the parcel No 66 does not result in any new information.

The base map presents Figure 2 . 


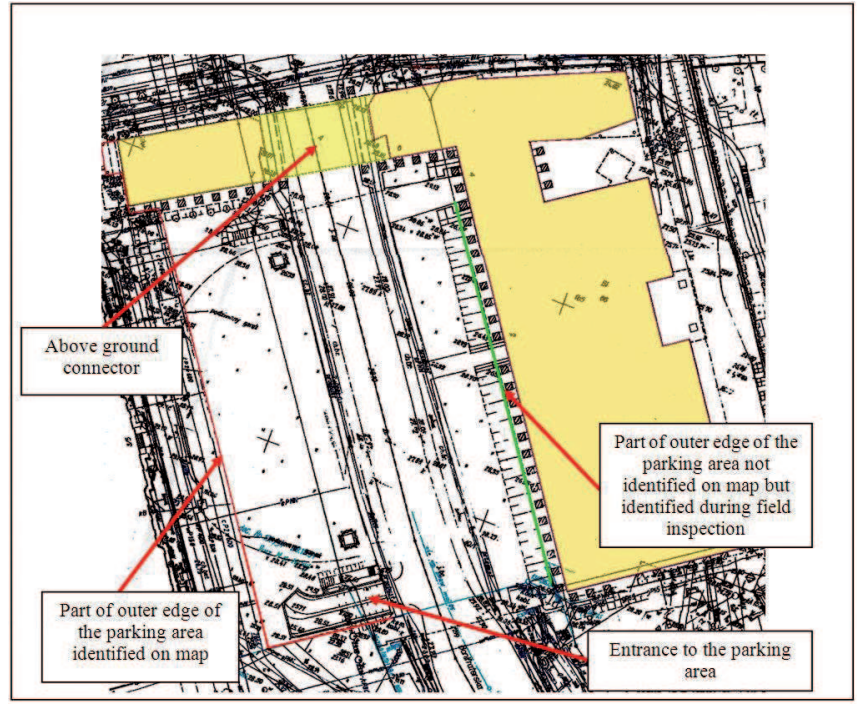

Fig. 2. Test object No 1 - base map

Source: based on map from The Office of Geodesy and Cadastre for the City of Warsaw - author

As it turns out from the performed analysis, except the information about the existence of one, underground storey, the cadastre does not include spatial information concerning the underground parking area. Land register does not contain information about the underground parking area either. The same situation happens in the case of the above-ground part of the building, located above the street. It is also not possible to record limited material rights in the case of two parcels, on which the road is located, since land registers have not been established for those parcels. For other parcels, although the land registers exist, those rights have not been recorded, which may result from the fact that all parcels belong to the "state entities". The base map is the source of some spatial information, but is does not present the situation related to the underground connection between the parking area and the building. In this case, it is not easy to identify the outer outline of the underground parking area - it is necessary to review the design documentation.

This case illustrates, that the base map does not always completely reflect the spatial conditions.

\subsection{Underground tunnel - test object No 2}

The issue related to underground tunnels occur in many places of the city, but they are not the subject of cadastral recording. This results from the fact that parcels, which are used as roads, are the property of the state or the city. In general, the road administrator is established, which is responsible for administration of such objects. Many of those objects cross other objects in the space (a road on the terrain surface with a road in 
a tunnel, a road on the terrain surface with a viaduct road etc.). For such cases, the Polish cadastre assumes creation of separate land parcels, following the strict rules.

In the case when railway lines, public roads, inner sea routes and inland water routes cross each other, the following rules are applied for specification of borders of land parcels:

- inner sea waters and inland waters, with the exception of water flowing in pipelines or in covered canals, are divided by railway lines and public roads into separate land parcels;

- railway lines divide public roads into separate land parcels;

- roads of higher category divide roads of lower category into separate land parcels;

- public roads of the same category are mutually divided into separate land parcels following the decisions existing in cadastral records;

- roads located on the surface divide roads in tunnels and roads on viaducts into separate parcels.

The example of a tunnel, which crosses the road located on the terrain surface, is the test object No 2. Under the main thoroughfare of the city, located in the very centre of the city (which is overloaded in rush hours), a tunnel has been built, which ensures the collision-free entrance into traffic coming from other parts of the city, as well the access to parking areas in front of the Palace of Culture and Science, being one of the biggest buildings in the city centre (Figure 3 ).

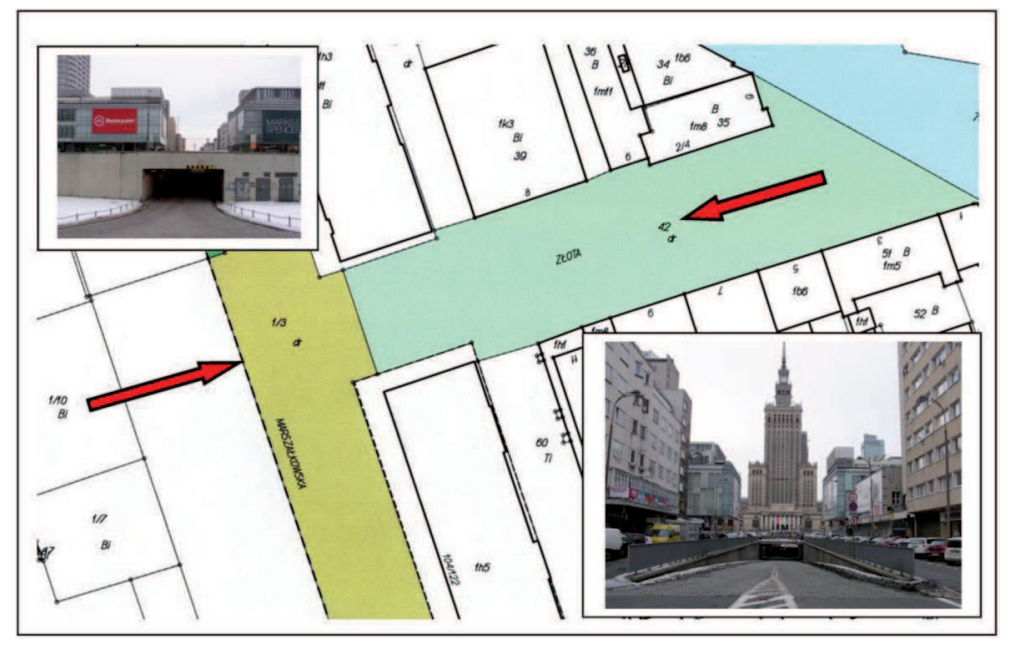

Fig. 3. Test object No 2 - cadastral map

Source: The Office of Geodesy and Cadastre for the City of Warsaw - maps, photographs - author

The investigated object is not presented on the cadastral map, which presents the system of parcels resulting from the above rules. The superior road, located on the terrain surface is included in two "complete-continuous" parcels (two - as a result of 
situating the border of the cadastral district in its centre), and the road in the tunnel, has been somehow "cut-off" as the cadastral parcel, at the joint with the surface road.

The base map (Figure 4) presents the same boundaries of cadastral parcels, since it contains boundaries of parcels, but additionally, it also presents the outer edges of the tunnel, what presents the better image of the reality.

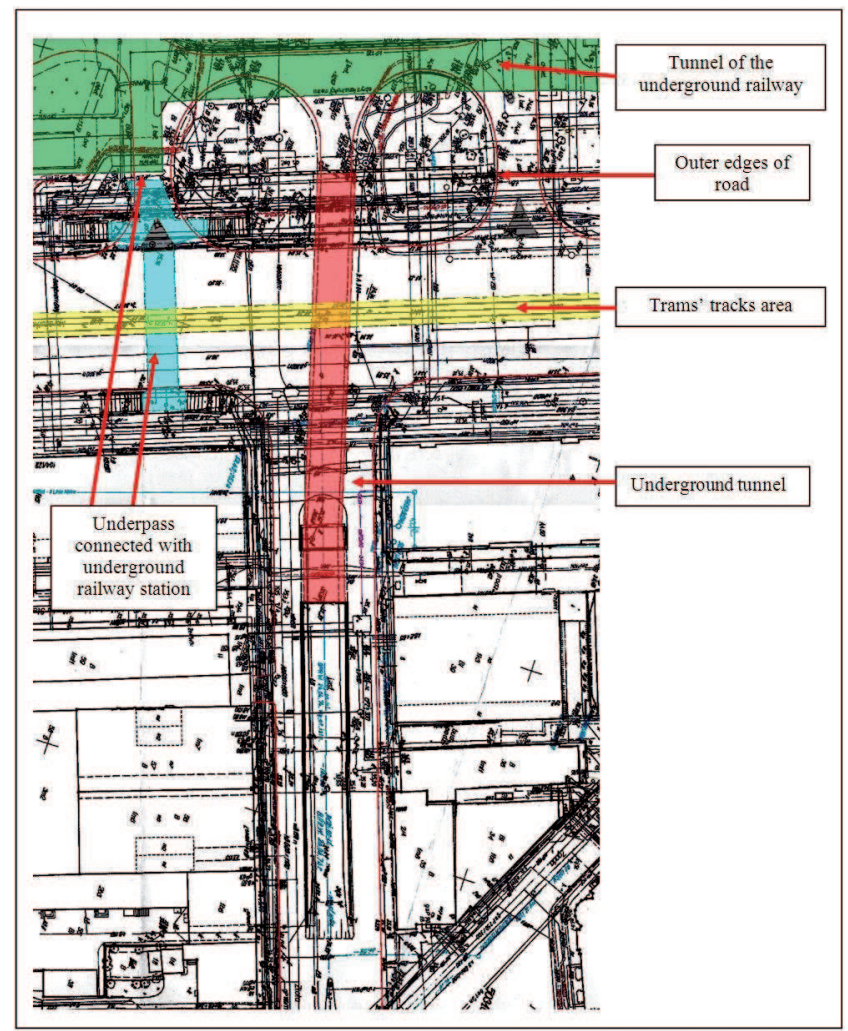

Fig. 4. Test object No 2 - base map

Source: based on map from The Office of Geodesy and Cadastre for the City of Warsaw - author

\subsection{Overlapping buildings - Test object No 3}

The next example concerns two private buildings located in the centre of Warsaw. As it turns out from the cadastral records, the building located on the land parcel No 60 does not have the underground part; it has only 11 above-ground storeys. The building is located on the parcel of the city of Warsaw, which established the right to perpetual lease for 11 entities, which - following legal regulations - are perpetual co-leaseholders of the land and, at the same time, they are the co-owners of the building (a separate building property). The cadastral map presents Figure 5. 


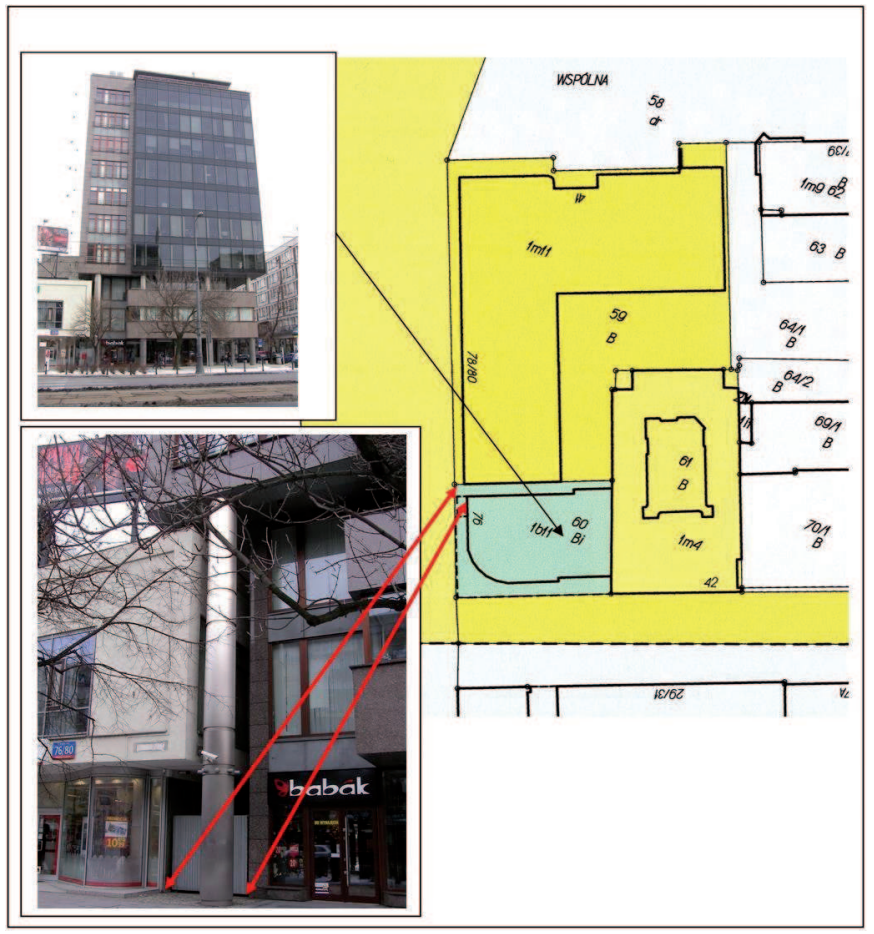

Fig. 5. Test object No 3 - cadastral map

Source: The Office of Geodesy and Cadastre for the City of Warsaw - map, photographs - author

It turns out from the presented cadastral map, that the building from the parcel No 59 joins the border of the parcel No 60; the same situation occurs on the field. Following the cadastral map, the building on the parcel No 60 does not join the border (the free space between the buildings exists). This has been also confirmed by field inspection. The field situation corresponds to the cadastral map on the level of the first storey of the buildings only, in the upper storeys it highly differs from the presentation in the cadastre.

This results from the fact that the building on the parcel No 60 is, in its above-ground part, hanging above the building from the parcel No 59 and building on the parcel No 59 is, in its above-ground part, hanging under the building from the parcel No 60 .

The building located on the parcel No 59 is older and it may be assumed that the owners agreed no to demolish the old building, which violated the parcel border and to hang the new building above the existing one. Unfortunately, analysis of records from the cadastre and from the land register has not resulted in specification of limited material rights to the parcel, where - following the author's opinion - the building enters the parcel's space somehow. Therefore, "formal" explanation of that situation cannot be found in any of the above public registers.

The next available document, i.e. the base map (Figure 6), also presents the discussed objects. 


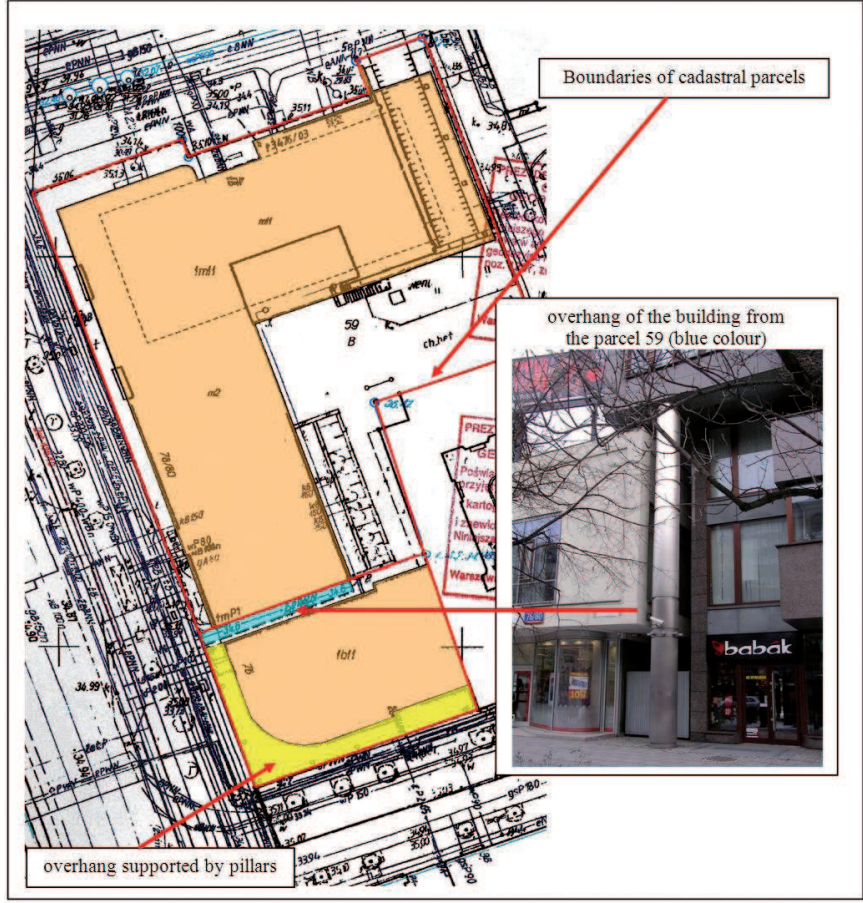

Fig. 6. Test object No 3 - base map

Source: based on map from The Office of Geodesy and Cadastre for the City of Warsaw - author, photograph - author

On the base map the outlines of the analysed buildings are identical with those presented on the cadastral map, providing that the base map additionally presents the overhang of the building from the parcel No 59 (with a dashed line). For the building from the parcel No 60, except of the, marked in yellow (which is also visible on the cadastral map) information concerning the part of the building hanging above the building from the parcel No 59, is missing.

Thus, the discussed situation could not have been registered either by the cadastre, or by the land register; it could not be presented on the base map by symbols either.

\subsection{Private premises above public road - Test object No 4}

The next analysed object concerns the residential building together with private premises, located in the centre of Warsaw. What is important from the point of view of the investigated issues, is the fact that the building is partially hung over the public road. Entrances to staircases, which lead to entrances to particular apartments, are situated in the left and right sides of the above-ground parts of the building; they are accessible from pavements for pedestrians, which run on both sides of the street. 
Physical appearance of the test object no 4 is presented in the Figure 7. The cadastral map is presented in the Figure 8.

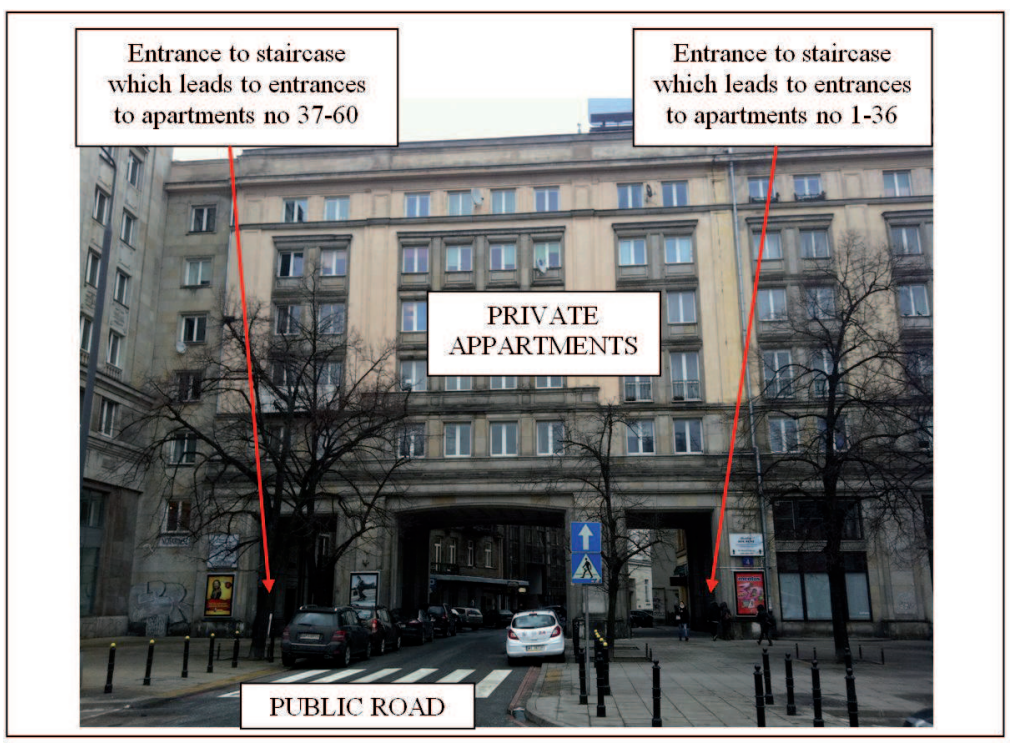

Fig. 7. Test object No 4

Source: author

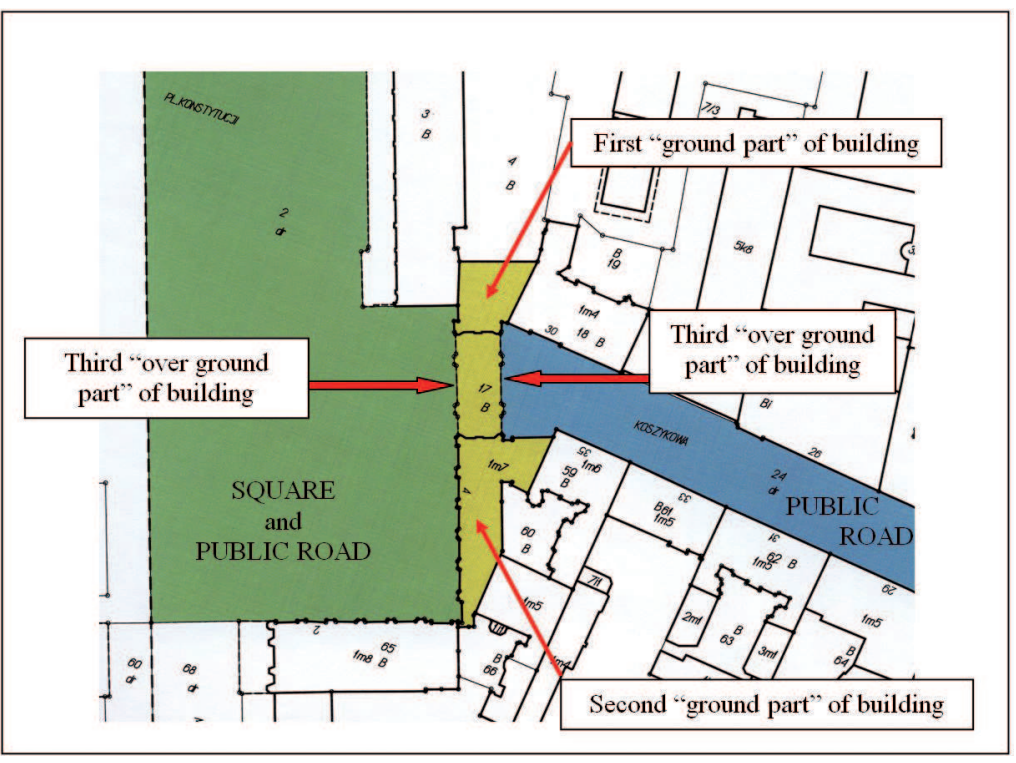

Fig. 8. Test object No 4 - cadastral map

Source: based on map from The Office of Geodesy and Cadastre for the City of Warsaw - author 
The outline of the building is registered on the map in such a way that the continuous line marks the outer outlines of the building, founded on the ground (two parts) and the dashed line marks the part of the building, which hangs over the street. The difficulty in interpretation of this situation, basing on the paper printout, results from separation of the cadastral parcel along the outer outline of the building (the building outline covers the border of the cadastral parcel - the dashed line overlaps the continuous line, which symbolises the parcel border). In the system the building is considered as one object, marked $1 \mathrm{~m} 7$ ( $1 \mathrm{~m} 7$ means the first building on the given cadastral parcel, functioning as the apartment building with 7 complete above-ground storeys). Besides, three cadastral parcels separate for each of the above parts, have not been established.

The analysis of records in the descriptive part of the cadastre and land register proved, that the City of Warsaw is the owner of the land parcel under the entire building (the cadastral parcel No 17). Private individuals are owners of separate apartments and business premises and they have the right of co-leasehold (separate shares are determined for particular owners) in the parcel, which is the property of the City of Warsaw. They also have the right of co-ownership of common parts of the building. Fifty five premises have been separated so far, they were sold to private individuals. Remaining premises are the property of the city, which administers the resources, i.e. the President of Warsaw.

Thus, each owner of premises has the partial share in the entire cadastral parcel (leasehold) and pays the tax for the real estate, which results from that share. The land is utilised by all, as the commonly used public road. Owners of premises cannot use that parcel in the same way as in the case when the parcel would be the common, "non- road" parcel, being the common real estate (the parcel on which there is located the building with premises). Therefore, they cannot fence that parcel or forbid entering it. Additionally, they are imposed by discomfort resulting from the fact that the street runs under the building (noise, pollution, poor thermal insulation etc.).

As it may be seen, the Polish cadastral system is not prepared for proper registration of such cases. The property should be separated "vertically", which should be compliant with law, but it also should be just, considering taxes, which must be paid by owners of premises (private individuals). This situation requires implementation of the 3D cadastre in Poland.

\section{Final remarks and conclusions}

Research works concerning such issues as premises in the cadastre, as well as other spatial objects has been conducted at the Department of Cadastre and Land Management Warsaw University of Technology.

The author performed, among other things, the analysis of existing solutions performed in the field of three-dimensional (3D) cadastres in selected European Union countries. Experiences gained in Netherlands (Karabin, 2008), Sweden (Karabin, 2007), Denmark (Góźdź, 2008) have been reviewed. Solutions applied in the countries, which 
are not the European Union members, i.e. Norway (Góźdź, 2008) and Israel (Karabin 2009, Karabin 2010), have also been considered.

„2nd International Workshop on 3D Cadastres”, held on 16-18 November 2011 in Delft, the Netherlands allowed for detailed analysis of present conditions and directions of development of cadastral solutions, existing in the world, related to registration of $3 \mathrm{D}$ objects.

Unfortunately, there are no legal regulations concerning the 3D cadastre in Poland. However, spatial objects, such as buildings and premises, are recorded, but - as it turns out from results of investigations performed by the author - existing ways of registration are not satisfactory for more complex spatial objects. The way of registration of spatial objects in the cadastre and, probably, the catalogue of those objects itself, should be modified, according to the author's opinion.

At present, the lack of registration of untypical objects in the cadastre is not the subject of wide discussions in the surveyors' society in Poland. As it is presented in the paper, the "untypical" situations concern such public objects and parcels, where there are no conflicts with private entities. Following the author's opinion, the current situation creates barriers for many investments and makes the division of space between various owners (a public entity - a private entity, a private entity - a private entity) impossible.

As it is seen from the analysed cases, for many of them the base map contains sufficient information on spatial elements (projection of the plane). The way of updating the base map may be considered as an advantage; it is performed as a result of surveys related to the as-built investment of buildings, underground installations, as a result of implementation surveys, performed for the needs of making documentation concerning division an delimitation of properties, and before commencement of any investment units. The map developed for designing purposes, is created using the base map (as the basic material) - updated for the appropriate area. Therefore, this material is used for implementation of various projects and the cadastral map is included in its content.

Following the author's opinion, if Poland concerned introduction of the complete version of the true 3D cadastre, i.e. containing spatial data about objects, which are not the cadastral objects at present - the base map should become the basic source of information about extent of those objects.

As said by the author (Karabin, 2011b), the content of the base map is sufficient to identify the spatial extent of those objects in the $x, y$ plane, and, for the technical infrastructure installations in the vertical plane as well, since heights of particular elements of that infrastructure (conduits, manholes etc.) are also specified. The body which maintains the base map (the same body maintains the cadastre) has the complete surveying documents concerning those objects in the archive.

The research proved, that introduction of the 3D cadastre in its simplified version (3D tags), i.e. without introduction of 3D spatial parcels, is possible with relatively low financial inputs, comparing to those required for surveying the objects from the very beginning, since the base map and source documents contain sufficient information concerning locations of those objects and they should be utilised for that purpose. It 
was the main conclusion in Karabin (2011b). But test objects no 3 and 4 (where two public ownership meet in the vertical space public ownership, and public ownerships meets private ownership) showed that only introduction of the complete version of the so called true 3D cadastre will ensure clear vertical division of rights and extent of rights.

Final remark is, that in Poland we should introduce 3D cadastre in future.

\section{Acknowledgments}

I wish to express my sincere appreciation to Mrs Ewa Helsztyńska. Thank You for doing me a real favour and invaluable help with language check. I would like to thank very much Reviewers for important comments and reviews. It is extremely kind of You Mrs Elżbieta Bielecka to enable me to publish the results of research works in Geodesy and Cartography semiannual journal of Committee of Geodesy of Polish Academy of Sciences.

\section{References}

Acharya, B. (2011). Prospects of $3 D$ Cadastre in Nepal. In Proceedings $2^{\text {nd }}$ International Workshop on $3 D$ Cadastres - Delft Netherlands, 16-18 November 2011 (pp. 241-254). Copenhagen, Denmark: International Federation de Geometres (FIG).

Aien, A., Kalantari M., Rajabifard A., Williamson I. \& Bennett R. (2011). Advanced Principles of 3D Cadastral Data Modelling. In Proceedings $2^{\text {nd }}$ International Workshop on $3 D$ Cadastres - Delft Netherlands, 16-18 November 2011 (pp. 377-396). Copenhagen, Denmark: International Federation de Geometres (FIG).

Minister of Regional Development and Housing. (2001). Decree of the of March $29^{\text {th }} 2001$ the Cadastral Law. Warsaw: Journal of Laws on 02 June 2001, No. 38, entry 454.

Council of Ministers. (1999). Decree of the of December 30th 1999 on Classification of Fixed Assets. Warsaw: Journal of Laws on 01 January 2000, No. 112, entry 1316.

Erba, D. \& Graciani S., (2011). 3D Cadastre in Argentina: Maps and Future Perspectives. In Proceedings $2^{\text {nd }}$ International Workshop on 3D Cadastres - Delft Netherlands, 16-18 November 2011 (pp15-30). Copenhagen, Denmark: International Federation de Geometres (FIG).

Góźdź, K. (2008). Analysis of foreign solutions in the field of registration of 3D objects in the cadastre and opportunities to implement them in Poland. Unpublished Master Thesis, Department of Cadastre and Land Management, Faculty of Geodesy and Cartography, Warsaw University of Technology.

Guo, R., Ying S., Li L. Luo P.,\&Van Oosterom P., (2011). A Multi-jurisdiction Case Study of 3D Cadastre in Shenzhen, China as Experiment using the LADM. In Proceedings $2^{\text {nd }}$ International Workshop on 3D Cadastres - Delft Netherlands, 16-18 November 2011 (pp. 31-50). Copenhagen, Denmark: International Federation de Geometres (FIG).

Iván, G. (2011). 3D Cadastre Development in Hungary. In Proceedings $2^{\text {nd }}$ International Workshop on 3D Cadastres - Delft Netherlands, 16-18 November 2011 (pp. 453-460) Copenhagen, Denmark: International Federation de Geometres (FIG).

Karabin, M. (2007). Analysis of existing solutions in the field of three-dimensional (3D) cadastral systems in the European Union states (part 1). Geodetic Review, 12(2007), 4-7.

Karabin, M. (2008). Analysis of existing solutions in the field of three-dimensional (3D) cadastral systems in the European Union states (part 2). Geodetic Review, 1(2008), 3-8. 
Karabin, M. (2009). 3D cadastre issues using the example of solutions performed in Israel (part 1) Geodetic Review, 12(2009), 8-13.

Karabin, M. (2010). 3D cadastre issues using the example of solutions performed in Israel (part 2) Geodetic Review, 1(2010), 3-7.

Karabin, M. (2011a). Registration of the Premises in 2D Cadastral System in Poland. In FIG Working Week 2011 „Bridging the Gap between Cultures”, Marrakech, Morocco, 18-22 May 2011, article no 4818 (available on www.oicrf.org). Marrakech, Marocco: International Federation de Geometres (FIG).

Karabin, M. (2011b). Rules concerned registration of the spatial objects in Poland in the context of 3D cadaster's requirements. In Proceedings $2^{\text {nd }}$ International Workshop on 3D Cadastres - Delft Netherlands, 16-18 November 2011 (pp. 433-452). Copenhagen, Denmark: International Federation de Geometres (FIG).

Minister of Regional Development and Housing (2001). Decree on lands and buildings register. Warsaw: Journal of Laws on 2 May 2001 No 38, entry 434.

Navratil, G. \& Unger E., (2011). Height Systems for 3D Cadastres. In Proceedings $2^{\text {nd }}$ International Workshop on 3D Cadastres - Delft Netherlands, 16-18 November 2011 (pp. 51-64). Copenhagen, Denmark: International Federation de Geometres (FIG).

Polish Parliament (1989). The Act of May 17, 1989 The Geodetic and Cartographic Law. Warsaw: Journal of Laws on 2010 No 193 entry 1287.

Polish Parliament (1964).The Act of April 23, 1964 The Civil Code. Warsaw: Journal of Laws on 1964 No 16 entry 93.

Thompson, R. \& Van Oosterom P. (2011). Axiomatic Definition of Valid 3D Parcels, potentially in a Space Partition. In Proceedings $2^{\text {nd }}$ International Workshop on 3D Cadastres - Delft Netherlands, 16-18 November 2011 (397-416). Copenhagen, Denmark: International Federation de Geometres (FIG).

Tsiliakou, E. \& Dimopoulou E. (2011). Adjusting the 2D Hellenic Cadastre to the Complex 3D World - Possibilities and Constraints. In Proceedings $2^{\text {nd }}$ International Workshop on 3D Cadastres - Delft Netherlands, 16-18 November 2011 (pp. 115-136). Copenhagen, Denmark: International Federation de Geometres (FIG).

Vučić, N., Roić M. \& Kapović Z. (2011). Current Situation and Prospect of 3D Cadastre in Croatia. In Proceedings $2^{\text {nd }}$ International Workshop on 3D Cadastres - Delft Netherlands, 16-18 November 2011 (pp. 255-270). Copenhagen, Denmark: International Federation de Geometres (FIG).

Ying, S., Guo R. Li L. \& Van Oosterom P., Ledoux H., Stoter J. (2011). Design and Development of a 3D Cadastral System Prototype based on the LADM and 3D Topology. In Proceedings ${ }^{2 n d}$ International Workshop on 3D Cadastres - Delft Netherlands, 16-18 November 2011 (pp. 167-188). Copenhagen, Denmark: International Federation de Geometres (FIG). 


\section{Rejestracja nietypowych obiektów 3D w polskim katastrze - czy istnieje potrzeba wdrożenia} katastru 3D?

\section{Karabin Marcin}

Politechnika Warszawska, Wydział Geodezji i Kartografii Zakład Katastru i Gospodarki Nieruchomościami, Plac Politechniki 1, 00-661 Warszawa, Polska e-mail: M.Karabin@interia.pl

\section{Streszczenie}

Polski system katastralny składa się z dwóch rejestrów: ewidencji gruntów i budynków (katastru nieruchomości) oraz ksiąg wieczystych. W ewidencji gruntów i budynków (katastrze nieruchomości) rejestrowane są dane o położeniu (w dwuwymiarowym układzie współrzędnych), atrybuty oraz dane o właścicielach obiektów katastralnych (działek, budynków i lokali), w księgach wieczystych oprócz danych właścicielskich, inne prawa do nieruchomości.

Rejestracja działki bez obiektów przestrzennych położonych na jej powierzchni nie stanowi problemu. Także rejestracja budynków i lokali w typowych przypadkach nie stanowi trudności. Sytuacja staje się bardziej skomplikowana w przypadku wielokrotnego użytkowania przestrzeni powyżej lub poniżej powierzchni działki oraz w przypadku budynków o złożonej konstrukcji.

$\mathrm{W}$ artykule przedstawiono zasady związane z rejestracją nietypowych obiektów 3D położonych na terenie miasta Warszawy. Zaprezentowano wyniki analizy zapisów dotyczących rejestracji tych obiektów ewidencji gruntów i budynków (katastrze nieruchomości) oraz praw do nich zapisanych księgach wieczystych. Artykuł stanowi kolejną część badań, w której autor stara się udzielić odpowiedzi na pytanie czy rzeczywiście istnieje potrzeba wdrożenia katastru 3D w Polsce. 